management of lupus. Although none of these drugs has been as thoroughly studied as cyclophosphamide, there is no evidence to suggest that any of them approaches the efficacy observed with cyclophosphamide. The antimalarial hydroxychloroquine has come to assume a prominent role in the therapy of most lupus patients, albeit with some concern as to whether it can ever be safely discontinued. ${ }^{9}$ There is a large clinical experience with low dose, daily azathioprine and, because of its more reassuring record of safety, many physicians continue to use this drug instead of cyclophosphamide. There is much less clinical experience with drugs such as low dose, weekly methotrexate $^{10}$ or cyclosporin, ${ }^{11}$ but available evidence would seem to suggest a role for these drugs in moderately active disease.

Improvements in the therapy of lupus will require continued investments in clinical trials of the disease. Among the more promising interventions in immediate prospect are new nucleoside analogues that have a prolonged effect on immune function, ${ }^{12}$ androgenic steroids, ${ }^{13}$ and biological products. ${ }^{14}$ It seems reasonable to assume these may have a clinical impact in lupus therapy in the very near future. However, perhaps of far greater importance, are possible therapeutic approaches that would correct the fundamental immune abnormalities responsible for lupus. In particular, the induction of immune tolerance to autoantigens, as has been attempted in studies of patients with rheumatoid arthritis ${ }^{15}$ or multiple sclerosis, ${ }^{16}$ would seem to be a highly worthy subject for future clinical investigation. Moreover, it is not too premature to begin consideration of reconstitution of the immune system by bone marrow transplantation ${ }^{17}$ or, ultimately, selective gene therapy. Basic and clinical studies have begun the search for candidate genes associated with autoimmunity, ${ }^{18-20}$ but considerably more work will be required before clinical protocols for gene therapy of the disease can be developed.

JOHN H KLIPPEL
1 Klippel J H. Systemic lupus erythematosus: treatment-related complications superimposed on chronic disease. $¥ A M A 1990 ; 263: 1812-5$.

2 Boumpas D T, Austin H A, Vaughan E M, Klippel J H, Steinberg A D Balow J E. Severe lupus nephritis: controlled trial of pulse methylprednisolone versus two different regimens of pulse cyclophosphamide. Lancet 1992; 340: 741-4.

$3 \mathrm{Klippel} \mathrm{J} \mathrm{H.} \mathrm{Is} \mathrm{aggressive} \mathrm{therapy} \mathrm{effective} \mathrm{for} \mathrm{lupus?} \mathrm{In:} \mathrm{Sergent} \mathrm{J} \mathrm{S,} \mathrm{Panush}$ R S, eds. Controversies in clinical rheumatology. Rheumatic Disease Clinics of North America. Philadelphia: W B Saunders, 1993: 249-61.

4 Boumpas D T, Austin H A, Vaughan E M, Yarboro C H, Klippel J H, Balow J E. Risk for sustained amenorrhea in patients with systemic lupus erythematosus receiving intermittent pulse cyclophosphamide. Ann Intern Med 1993; 119: 366-9.

5 Vose J M, Reed E C, Pippert G C, et al. Mesna compared with continuous bladder irrigation as uroprotection during high-dose chemotherapy and transplantation: a randomized trial. $\mathcal{F}$ Clin Oncol 1993;11: 1306-10.

6 Zonzits E, Aberer W, Tappeiner G. Drug eruptions from mesna after cyclophosphamide treatment of patients with systemic lupus erythematosus and dermatomyositis. Arch Dermatol 1992; 128: 80-2.

7 Pryor B, Bologna S, Ernst C, Michalski S, Kahl L. Risk of malignancy in cyclophosphamide-treated SLE patients. Arthritis Rheum 1993; 36: S91 [Abstract]

8 Houssiau F A, D'Cruz D P, Haga H-J, Hughes G R V. Short course of weekly low-dose intravenous pulse cyclophosphamide in the treatment of lupus nephritis: A preliminary study. Lupus 1991; 1: 31-5.

9 The Canadian Hydroxychloroquine Study Group. A randomized study of the effect of withdrawing hydroxychloroquine sulfate in systemic lupus the effect of withdrawing hydroxychloroquine sulf

10 Le Blanc B A E W, Dagenais P, Urowitz M B, Gladman D D. Methotrexate in systemic lupus erythematosus. F Rheumatol 1994; 21 : 836-8.

11 Tokuda M, Kurata N, Mizoguchi A, et al. Effect of low-dose cyclosporin A on systemic lupus erythematosus disease activity. Arthritis Rheum 1994, 37: 551-8.

12 Saven A, Piro L D. 2-Chlordeoxyadenosine: a newer purine analog active in the treatment of indolent lymphoid malignancies. Ann Intern Med 1994, 120: 784-91.

13 van Vollenhoven R F, Engleman E G, Lambert R E, Lee Y S L, McGuire $\mathrm{J}$ L. Treatment of systemic lupus erythematosus with dehydroepiandrosterone. Interim analysis of a double-blinded randomized placebo-controlled clinical trial. Arthritis Rheum 1993; 36: S92 placebo-contract].

14 Stafford F J, Fleisher T A, Lee G, et al. A pilot study of anti-CD5 ricin A chain immunoconjugate in systemic lupus erythematosus. $\mathcal{F}$ Rheumato 1994; 21 : 2068-70.

15 Trentham D E, Dynesius-Trentham R A, Orav E J, et al. Oral administration of type II collagen improves rheumatoid arthritis. Science 1993; 261: 1727-30.

16 Weiner H L, Mackin G A, Matsui M, et al. Double-blind trial of oral tolerization with myelin antigen in multiple sclerosis. Science 1993; 259: $1321-4$.

17 Marmont A M. Immune ablation with stem-cell rescue: a possible cure for systemic lupus erythematosus? Lupus 1993; 2: 151-6.

18 Watanabe-Fukunaga $R$, Brannan C I, Copeland N G, Jenkins N A Nagata $\mathrm{S}$. Lymphoproliferative disorder in mice explained by defects in Fas antigen that mediates apoptosis. Nature 1992; 356: 314-7.

19 Wu J, Zhou T, Zhang J, He J, Gause W C, Mountz J D. Correction of accelerated autoimmune disease by early replacement of the mutated lpr gene with the normal Fas apoptosis gene in the T cells of transgenic MRLlpr/lpr mice. Proc Natl Acad Sci USA 1994; 91: 2344-8.

20 Mysler E, Bini P, Drappa J, et al. The apoptosis-1/Fas protein in human systemic lupus erythematosus. f Clin Invest 1994; 93: 1029-34.

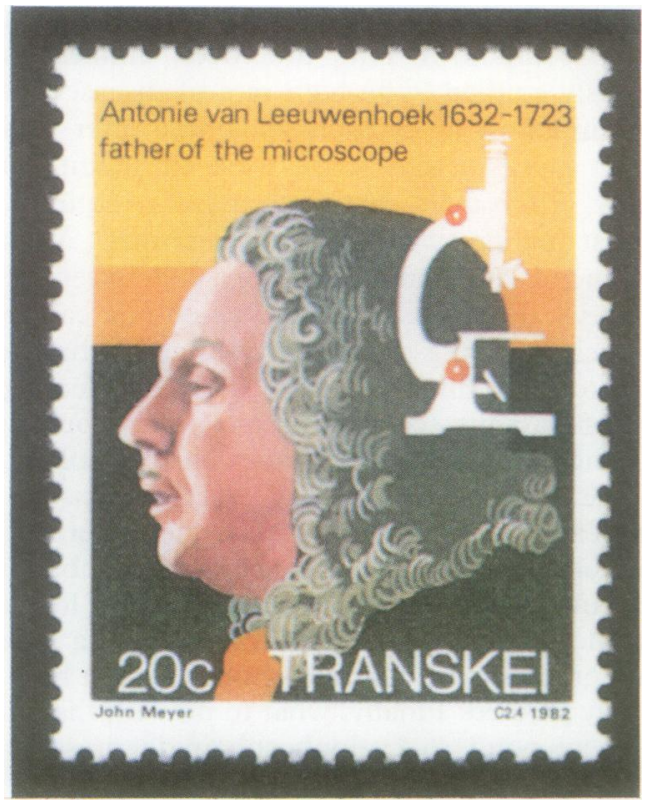

\section{Antoni Van LEEUWENHOEK (1632-1723)}

Antoni Van LEEUWENHOEK, a draper and a lens grinder in Holland, was one of the most remarkable amateurs of science the world has ever known. He described the fauna and flora of a world that was invisible to all but a few and the science of microbiology was born. He was not the first to refine the use of the magnifying glass or to use a microscope, but he was the first to use it most effectively. He was able to magnify up to 200 magnifications.

He had a half a century of correspondence with the English Medical Society, all written in Dutch, but later translated into Latin or into English. He was elected to the Society of 1680 . As new awards came to him he acknowledged one from the University of Louvain: " $M y$ work which I have done for many a long year was not pursued in order to gain praise but chiefly from a craving after knowledge".

Among his studies he demonstrated striped voluntary muscle and the crystals of uric acid and a variety of microorganisms. He made no effort to correlate disease with his findings.

He is commemorated on stamps of the Netherlands and Transkei. 